\title{
The Structured Dependency of the Elderly: A Greation of Social Policy in the Twentieth Century*
}

\author{
PETER TOWNSEND $\dagger$
}

\section{ABSTRACT}

If we are to develop better methods of integrating elderly people into society then above all we need a better sociology of the ageing and the aged. In this paper I wish to put forward the thesis that the dependency of the elderly in the twentieth century is being manufacturcd socially and that its severity is unneccssary. ${ }^{1}$ The process can therefore be revised or at least modified. Certain major influences, which will be discussed below, are steadily deepening, or widening that dependency. Therc is the imposition, and acceptance, of earlier retirement; the legitimation of low income; the denial of rights to self-determination in institutions; and the construction of community services for recipients assumed to be predominantly passive.

\section{Introduction}

For many years after the Second World War scientific research into old age was extraordinarily restricted, and only latterly has fundamental enquiry begun to assume a critical and wide-ranging and hence more constructive cohesion. The physical, mental, and social features of ageing were seen as natural, or as largely inevitable. Instead of asking what brought about the modern phenomenon of retirement and accentuated social dependency and the chances of isolation and extreme deprivation in old age, or what explained the mainly custodial and impersonal forms of institutional care for the elderly and the large-scale use to which they were put, many scientists, scholars and practitioners have asked only how

* Revised text of an address to the Annual Meeting of the Canadian Association of Gerontology, Saskatoon, Saskatchewan, November 1980.

$\uparrow$ Professor of Sociology, Department of Sociology, University of Essex, Wivenhoe Park, Colchester, Essex. 
can people adjust to retirement, or how can the burden for relatives or the state be lightened, or how can the administration of institutional care be made more efficient? The inexorable process by which the status of older people has been lowered, or rather, defined at a lowly level in the course of the development of the industrial societies, has been largely ignored. The cvolution of the economy, the state and social inequality has been taken for granted, and the implications of the trends for people as they become older neglected. Rather than ask how and why is society restricting life chances and opportunities at older ages, most scientists have directed their attention to the problems of elucidating adjustment so as to soften the impact of that adjustment but, indirectly, legitimate its operation.

This might be illustrated copiously from the literature on ageing, particularly compendia published in the United States between the r950s and 1970s, such as the Handbook of Social Gerontology $y^{2-3}$ and The Sociology of Ageing: Selected Readings. More recent examples are Old Age in European Society and The Economics of Individual and Population Ageing. ${ }^{4}$

\section{The Individualistic Approach to Ageing and the Origins of an Alternative Approach}

This emphasis on trying to explain individual ageing within a structure, and especially class structure, which was accepted without question, rather than trying to explain that structure, its interrelationships and its development, as a necessary precondition in the exposition of a theory about ageing and the aged, was shared by most social gerontologists. It was derived from neo-classical economic theory and the associated thinking of those working within the tradition of functionalism in sociology, as well as the more descriptive and empirical traditions of social work and social administration. The bias was towards individualistic instead of societal forms of explanation. Elsewhere I have characterized this as 'acquiescent functionalism', or the kind of theory of ageing which attributes the causation of problems to the difficulties of individual adjustment to ageing, retirement or physical decrescence, while acquiescing in the development of the state, the economy and inequality. ${ }^{5}$ Perhaps the single most important influence during this period in reflecting an individualistic interpretation was the work of the 'disengagement' theorists, in particular, Cumming and Henry. ${ }^{6-7}$ From the beginning there were those like the Israeli, Yonina Talmon, who challenged this interpretation ${ }^{8-10}$ and the normative assumptions of this theoretical approach came increasingly under close scrutiny. ${ }^{11}$ There were those who challenged in detail the evi- 
dence of occupational and social but also psychological disengagement. ${ }^{12}$ Alternative modes of explanation, whether of a radical structural or classoriented, or even broadly Marxist kind, have been slow in developing.

We can see the beginnings of theoretical reconstruction in the studies of residential institutions. There were those like Erving Goffman ${ }^{13}$ who called attention to the common forms and functions of different types of residential institutions and he made a powerful casc against the stultifying effects of the 'total institution'. But his case was rather unrelated to external economic and social determinants. On the other hand, there were those like David Rothman who sought to give an historical explanation for the development of residential institutions which was related to external determinants. He argued that asylums were not just an instrumental mechanism for dealing with specific problems, but werc symptomatic of general social developments. They exemplified 'the proper principles of social organizations and thus insure the safety of the Republic to promote its glory. ${ }^{14}$ This was an original and important contribution. So institutions were harsh social organizations and reflected external economic and cultural prioritics. Both writers turned attention to the influence of structural factors, whether the immediatc environment of a specific organization or of more general economic and cultural form. Other writers began to protest powerfully against the observed conditions of people in institutions, including the elderly. Notable examples were Henry and Roth and Eddy. ${ }^{15}$ And others have tried to relate the development of institutional care to a Marxist perspective in which the themes of the meagre distribution of resources, if not exploitation, and of social control, play a substantial part. Thus Andrew Scull argued in his book Decarceration that the increased emphasis by different governments on welfare or community care is attributable to the state's urgent need to cut the costs of social control. That is an uncomfortable and chilling thesis which deserves to be scrutinized seriously. After all, the 1834 Poor Law Amendment Act did much the same, and few historians now remain under any illusions about the intentions of social policy at that time. Just as others before him had undertaken the 'demystification' of the rolc of institutions, Scull went on to demystify the claims made for the alternative of community care. ${ }^{18} \mathrm{I}$ do not find his casc persuasive in relation to evidence of the subjective attitudes and experiences of older people. In a national study of residential institutions I found that even after many years' incarceration there were inmates who tended to retain strong desires to return to a home of their own. ${ }^{17}$ Nonetheless, his claim that, however desirable in principle, community care is often unsatisfactory in practice, is uncomfortably true. In the discussion of the functions of residential institutions publicly and within the professions there are a lot morc critics in Europe and certainly 
Britain than in the United States. It illustrates the sceptical view that deserves to be taken of economic and social developments which are pursued without regard to the elderly and the grudging and authoritarian services which are created directly for them.

\section{The Tasks Ahead}

Two levels of analysis therefore become necessary. One is to explain how the general position, status and functions of the elderly within existing society have been determined or established. The other is to examine and explain the kind of relationship within different structures which elderly people have, the roles they play and experience, concurrently and sequentially. The second is much more common in the literature but of not much help to understanding without explicit formulation in relation to the first. Let me discuss these in turn. We are too inclined to accept the existence of contemporary economic and social institutions as inevitable and necessary. Only by reminding ourselves repeatedly of the emergence and decline of certain kinds of institution in different countries in the span of less than a hundred years, and of the transformation of their functions, composition, systems of authority and independence can we achieve that degree of detachment necessary to a scientific perspective. The changes which are taking place in the external community and the whole system of institutions, and in the central value system and economic and political value systems of society, ramify and infuse the particular relationships between old people and others in the family, the community, and the social services. The full implications of this process need to be thoroughly understood. A good example is the history of the workhouse. This became a necessary ingredient of emerging capitalism. It was brought about by enclosure and new definitions of the private rights to property, and not just the need to establish a compliant workforce. There were bound to be victims of the operation of the new rules as well as a need in principle for examples of what would happen if the rules were broken. An Assistant Commissioner of the Poor Law wrote, 'Our object is to...establish therein a discipline so sevcre and repulsive as to make them a terror to the poor and prevent them from entering. ${ }^{18}$ The intention was to enforce the willingness to work and, at the same time, inhibit recourse to public relief. A growing number of elderly people were submitted to a style of life intended centrally for the able-bodied poor. For most of the igth century, admission to the work-house (later to become public assistance institutions) was seen more in relation to the individual's accommodation to society than society's creation of a system of control. As one commentator put it recently, admission 
"continued to be seen as a sign of individual moral decay and bad management among the working classes rather than as a consequence of social change and the economic order. In this way older people were seen to have caused 'a problem' for the payers of the poor rate and for those in authority. The situation was perceived as a social problem, the cause of which was the irresponsibility and imprudence of the inflated population of work-house inhabitants. ${ }^{19}$

In some respects the problem was therefore a direct creation of the system. Victorian morality was also strait-laced, as well as being deeply influenced by the work ethic, and in both respects there were consequences for the elderly in residential institutions. This affected access to relatives and the outside world and resulted in the segregation of the sexes internally, for example. One historian has lately shown that the consequences for the elderly were not only harsh in the decades following ${ }^{1} 8_{34}$ but were deliberately punitive in the 1870 s and 1880 s, when efforts were redoubled to implement the principles of the new Poor Law. ${ }^{20}$ In many countries it is arguable that evidence of this suffering can still be found, and is attributable to the inheritance, too little modified, of those self-same values. There are tendencies to withhold commitment of medical and occupational resources, depreciate individuality and foster passivity and dependence. Our task then is to properly trace and identify those forces and values which govern not just the arrangements made for older people in residential institutions, but the ideas with which we interpret those arrangements.

I am arguing, then, that society creates the framework of institutions and rules within which the general problems of the elderly emerge and, indeed, are manufactured. Decisions are being taken every day, in the management of the economy and in the maintenance and development of social institutions, which govern the position which the elderly occupy in national life, and these also contribute powerfully to the public consciousness of different meanings of ageing and old age. There are decisions familiar to all of us about the commitment of public expenditure which directly govern the services and bencfits of older people. Then there are decisions about employment, wages and taxation, transport, urban planning and housing which have a powerful indirect effect on the situation and standard of living of the elderly. And the question is not just one of the flow of resources to the elderly population and the determination of their matcrial amenities, but the scope for action and self-help on the part of the elderly which becomes feasible, and therefore the interpretation that they, and not only others, place upon their status and functions. 


\section{The Effects of Retirement in Promoting Increased Dependency}

Let me review the more crucial factors. Retirement has become a social phenomenon of vast importance in the short span of the last fifty years. According to statistics published by the International Labour Office, between 40 per cent and 70 per cent of men 65 and over in all industrial countries were still economically active in the r 930 s. But by the midrg6os, with the exception of Japan, where the percentage had declined only slightly, the proportion had shrunk dramatically to between io per cent and 40 per cent with the mean about 20 per cent. The reduction has continued during the I97os, though not so rapidly. This change cannot be attributed to changes in the risk of ill-health or disability, or the masking of disability in periods before substitute pensions were available. It is attributable to changes in the organization of work and in the kind of people wanted for work. Bigger work organizations, with more pronounced hierarchies, have become established and career promotion through the successive tiers of these hierarchies is regarded as normal and to be expected. The objectives of economic growth, productivity and increasingly rapid replacement of skills have been adopted within these organizational settings and, as a direct consequence, more workers at older ages have found themselves misplaced. In the late i 970 os another factor has become all-important. The development of multi-national corporations and improvements internationally in transport and communication have led to a deliberate shifting of manufacturing production to poor countries where the workforces can be paid very low wages. In 1975 the workforce of the overseas subsidiaries of German manufacturing industry represented 20 per cent of the manufacturing workforce in Germany itself. $^{21}$

Problems arise for companies and unions which can only be resolved by a kind of mass redundancy, which retirement has become. Retirement is in a real sense a euphemism for unemployment. The phenomenon has been enforced and is being enforced in a number of industrial countries at earlier ages and yet is, paradoxically, being represented as a social achicvement in capitalist and state socialist societies alike. The spread of retirement is interpreted as reflecting the success of campaigns on behalf of the rights of workers when they have 'earned a rest', and is associated with the rights of old people to peace and dignity. But many older, especially active, people deplore the termination of economic activity. ${ }^{22-23}$ People reaching retirement age do not welcome it as warmly as they had thought they would. Many who have retired deeply regret their inactivity or loss of status. The satisfaction which is expressed by some retired people is more what they think is expected of them, and more an assertion of hope, 
than a true representation of what they feel. Closer historical examination of retirement as a social institution shows that its adoption has also been associated with pressures to shed moral if not contractual obligations to loyal workers and to exclude certain groups of workers from the bargaining process. The public are encouraged to accept the lessened value to the economy of workers past certain ages. Changing technology and the successive adoption of forms of training and educational qualifications have encouraged over-valuation of the productive capacity of younger workers and under-valuation of the productive capacity of older workers. This has affected other priorities. Less consideration tends to be given in sickness and disability at older than at younger ages and, indeed, retirement is cavalierly associated with failing health and capacity. Thus the combined effects of industrial, economic and educational re-organization are leading to a more rigid stratification of the population by age.

In different countries the same process is now being extended to groups of workers below the previously agreed pensionable ages. One powerful influence upon the extension of the scope of retirement at the present time is high unemployment. It is convenient to governments to shift some of the total unemployed into the category of the retired. Sometimes unions share this point of view in order to reduce to manageable proportions the problems with which they are already dealing. Given the structure of preferment which I have already described, sympathies are aroused much more easily on behalf of the young than the middle-aged unemployed. There may be another, underlying, reason for more retirement. In economies where the rates of growth have been declining, especially relative to the rate of increase in non-manual and especially upper non-manual occupations, there has been an especially rapid increase in the numbers retired - much more rapid, that is, than the growth in population numbers of pensionable age. In most rich countries the numbers and percentage of professional, managerial and administrative workers receiving relatively high salaries has been increasing rapidly. When the shoe pinches, as it is now pinching in times of high inflation and low or non-existent rates of growth, the only way in which the growing number of relatively highpaid people can be accommodated without reducing their real levels of income is through savings from incomes allocated elsewhere. These groups are skilled in defending their relatively advantageous levels of renumeration. This is an underlying structural reason for the displacement of workers in late middle age into premature retirement. ${ }^{24}$ 


\section{The Effects of Pensions in Promoting Dependency}

While the institutionalization of retirement as a major social phenomenon in the very recent history of society has played a big part in fostering the material and psychological dependence of older people, the institutionalization of pensions and services has also played a major part. The propensity to poverty in old age could be said to be a function of low levels of resources, and restricted access to resources, relative to younger people. Secondly it is due to restricted access to the new styles and modes of living being promoted in the community. In Britain there is official evidence for the last 15 years of about ro per cent being in poverty, as defined by the state, and another $3^{\circ}$ per cent or $4^{\circ}$ per cent being on the margins in the sense that they are living at the state's standard or within 40 per cent of that standard. ${ }^{25-26}$ Independent measures suggest the first of these figures (1o per cent in poverty) is underestimated because of methodological shortcomings. ${ }^{27}$ Restriction of resources is determined by different causal factors. State pensions and other cash benefits administered centrally comprise the most important source of income for the clderly in most advanced industrial societies and the initial rate of state pensions after retirement, and the amount of substitute or supplementary benefits which are paid, after the pensionable age or upon retirement, tend to be low relative to the earnings of younger adults. In Britain, various studies put the net incomes of single or widowed retired people, allowing for dependants, at about a third, and of married couples less than half, of younger non-retired people. ${ }^{28-29}$ State help is offered on condition that people retire from paid employment and this status is imposed upon elderly people at a fixed chronological age, or they are persuaded to accept it as a social norm. Pension levels are defined in relation to subsistence needs, and are usually pitched considerably below net earnings during the period of paid employment. The initial rates of private or occupational pensions, with some exceptions, are also low relative to the earnings of young adults. Provisions for widows under the terms of these schemes have generally been poor and this fact, together with the failure of many such pensions to keep pace with inflation, explains why so many people formerly associated with nonmanual occupations, certainly in Britain, descend, along with their working-class counterparts, into poverty or near-poverty after retirement. Lacking access to many of the positions where sectional interests can be properly represented, the elderly find their position in a rapidly evolving economy getting worse. Their resources fail to keep pace in value with the resources of other groups in society; either certain forms of assets held, such as household goods and equipment and certain types of income from savings, and occupational pensions, depreciate in value absolutely or rela- 
tively to the rise in living standards, with increasing length of retirement, or many do not have, and have not in the past had, an opportunity of obtaining types of resources which are newly becoming available to younger people. What is more, greater exposure to certain forms of social desolation and isolation, brought about by the death of a spouse, the loss of close relatives or friends, and the decay of industries or city centres, as well as by retirement, tends to deprive the elderly of access to alternative or subsidiary resources and sometimes leads to additional costs. Liability to disablement restricts access to resources and, in the absence of compensating cash benefits and services, leads to additional costs for many which outweigh the savings consequent upon retirement.

There is a sharp contrast between the low status in which old people are held publicly and the regard in which they are held privately in their families. In the family age is of secondary importance. People are grandparents, parents, brothers or sisters and friends or neighbours first and foremost. Retirement from familial roles is a much more flexible contingency, dependent primarily upon health or disablement. In some respects the family also provides escape from the psychological and social bruises which can be inflicted externally, and up to a point provides meaningful activity and genuine respect. The positive contribution to the welfare of grandchildren and children of many elderly women is greatly underestimated just as their labour specifically on behalf of their husbands and in general on behalf of the economy throughout adult working life goes largely unrecognized. Capital and state separately or in combination, may have fostered the dependency of women within the family but, paradoxically, has created an independent system of interdependence, occupation, mutual respect and loyalty. The defensive and restorative mechanisms of the family temper the dependency created by the state. ${ }^{30}$

\section{The Effects of Residential Care in Creating Dependency}

Rich societics have still to come to terms with the engineering of retirement and mass poverty among the elderly in the twentieth century. These two are of course linked and they have been pre-eminent in creating the social dependency of the elderly. But their connection with the development of residential and community care is too frequently overlooked. When we turn to examine the part played by these two trends in fostering dependency it is important to understand how the assumptions of all the participants are already greatly affected by the facts of retirement and poverty. Not only do they materially restrict life chances. They govern the attitudes and not only the actions of professional staff, on the one hand, and elderly clients or residents, on the other. 


\section{I4 Peter Townsend}

A review of the history of residential developments and of the characteristics of the inmate populations shows that the institutions have been, and are, serving major functions other than those for which formally they were and are supposed to exist. In particular they have inhibited appeals in times of major stress for public help from the individual and the family, have operated as a cheap (because selective) substitute for public housing and community services, and have regulated public ideas of the lengths to which the family is expected to carry the burden of care. It is easier to see in the case of the former workhouses than perhaps in the case of residential Homes in the 1980 os how they discipline or even punish the individual and the family for transgressing conventional norms. Custodial regimes were established in the nineteenth and the early part of the twentieth centuries which have lingered on - because old buildings have continued to be used or staff who were employed before the passage of new legislation have been retained in new circumstances, and little thought has been given to the purpose and interconnections of the whole system. In the United States and Canada, for example, the poor farm continued even into the I920s and 1930s. When Canada was primarily agricultural, welfare was essentially a local problem. Nova Scotia and New Brunswick, for example, had the poor law on the British model on the statute book at the time of confederation. Ontario, while specifically excluding the poor law from its statutes at the time of confederation, inherited all the traditional attitudes and practices of local poor relief. In New Brunswick the poor law of 1786 was only repealed in 1960 , and it was not until $195^{8}$ that Nova Scotia replaced its poor law by a general assistance act. $^{31}$

In Britain the termination of poor law practices was prematurely announced on several occasions during this century. From the general mixed workhouse different types of separately administered institutions for the mentally handicapped, chronic sick, mentally ill and elderly evolved haphazardly, without much or any controlled relationship to the multiple handicaps experienced in extreme old age. There were key periods of administrative specialization. In the middle of the nineteenth century infirmaries began to be established in the workhouses and a separate system of county asylums was developed but, as Thomson has lately shown, there was a prolonged and partially successful attempt in the $1870 \mathrm{os}$ and 1880 s to apply the harsh principles of the New Poor Law to the elderly. With some exceptions life in institutions for the elderly remained miserable. ${ }^{32}$ After the Local Government Act of 1929 many former workhouses and workhouse infirmaries were converted into local authority hospitals. In 1948 the remaining former workhouses, used as public assistance institutions during the 193 os and 1940s, either became National Health Service 
hospitals for the chronic sick or were arbitrarily assigned to the local authorities as residential accommodation under Part III of the National Assistance Act. At no stage was a considered attempt made to work out how much of the accommodation should be used for what purpose, to investigate the special needs of those advanced in years or to examine the relationship between different types of institutional services. This came to bc admitted officially by the Department of Health and Social Security in the mid-1970s. ${ }^{33}$

The National Assistance Act drew in some measure upon reports at the end of the war on services for the elderly and ushered in the policy first of modernizing and then of building 'small' residential homes, but even this policy was given relatively little thought and backing. Anyone who now visits the three types of institutions - geriatric hospitals, psychiatric hospitals and residential Homes - will note glaring contrasts, not only in standards of furnishing and amenities, but in daily routine, order, appearance and opportunities for occupation. How far could it be argued that the different regimes and ideologies are coincident with, or even roughly appropriate to, the needs of their inmate population? There is an increasing literature in Britain about the mismatch of inmate needs and types of residential institutions. ${ }^{34-39}$

How appropriate is the distribution of population among the three types? And is the total population of the three types of institutions far too high or low or about right? By asking such questions we direct attention towards the historical, organizational and inter-organizational determinants of form and scale. I have argued elsewhere that three forms of hospital for long-stay patients should in time be merged and that kind of care provided in small hospitals with homely management regimes. Many of the others still in hospital or residential Homes could live in sheltered or special housing supported in part by domiciliary services. ${ }^{40}$

\section{Social Rather than Physical and Mental Dependence}

Evidence of the imposition of dependency upon inmates can be divided into at least two categories - physical or mental evidence about individual capacities which shows that people need not be there and evidence of social restriction. The relevant legislation places a duty on local authorities to provide residential Homes for those 'in need of care and attention'. Tests of mental, physical and social capacity can in principle be applied to the different inmate populations to find how far formal conditions for inmate status are in fact met. Tests of mental capacity are less common than of physical capacity but have been attempted. In a 1963 national survey, for example, $4^{2}$ per cent of elderly psychiatric patients were said 
by staff to be severely mentally impaired. Fifty-five per cent were said to have no incapacity or only slight or moderate incapacity. In short, independent checks or assessments of mental conditions can be made to explore need in relation to organizational function. ${ }^{41}$

During the last three decades extensive evidence about capacities for self-care on the part of residents has been published. There are of course different options in converting conceptualization into measurement. ${ }^{22}$ In a 1958-59 survey of England and Wales, 74 per cent of new residents of Homes were found to have only slight or no incapacity and a survey in I 963 of all residents produced a roughly comparable figure of $5^{8}$ per cent. ${ }^{43}$ A r 969 survey of Scotland showed that 67 per cent of residents of local authority homes were able to wash, dress and use toilets on their own initiative, and 45 per cent were defined as 'fit', that is, having complete capacity for self-care. The authors concluded that 54 per cent could have lived in sheltered housing. ${ }^{44} \mathrm{~A}$ DHSS census in 1970 showed that as many as 45 per cent in local authority homes were 'minimally dependent' in the sense that they were 'mobile without assistance, continent, able to feed themselves and mentally alert'. ${ }^{35}$ While this kind of evidence can be quoted from a wide range of reports it should not be forgotten that at the other extreme there is evidence of a substantial minority of residents who are extremely frail. In the Scottish survey, for example, i4 per cent were classified as requiring hospital care. ${ }^{46}$

During the 1970 os a succession of further studies has produced substantially more evidence. Despite a tendency for the average age of residents of homes to rise and representations on the part of staff understandably to be made about the increasing numbers of very frail residents, evidence continues to be published from different parts of the country testifying to the non-frailty of a substantial proportion of the residents. ${ }^{47-58}$ Let me illustrate from a report published in 1980. Booth arranged for detailed questions to be put about ability for self-care, continence and social integration, of the residents of one local authority.

'Over one-fifth (22.1 per cent) of all residents in homes in Sheffield were assessed as requiring care and support of a degree which rendered them substantially dependent on residential staff. On the other hand, the census also shows that a much larger proportion of residents (37.3 per cent of the total) were rated as largely independent in their personal functioning within the home; and bearing in mind the possibility that the method of assessment may have tended to over-predict the extent of dependency, then the estimate is likely to under-represent the time ratio of active and able residents in the homes. ${ }^{\text {'s }}$

The concept of dependency includes more than is implied by this extract ${ }^{59}$ but Booth brings out something which is not acknowledged in 
many of the studies - that staff must not be treated as disinterested or unbiassed witnesses of residents' capacities. Because of organizational constraints and the formal expectations placed upon them in fulfilling their roles staff are liable to take an unduly pessimistic view of residents' capacities. There is a double problem. On the one hand there are very disabled residents. Staff are acutely conscious of the difficulties of managing severely disabled residents. Medical, psychiatric and nursing skills in residential institutions are generally sparse. In previous decades many of these elderly residents would have been cared for in hospital, but there has becn a reduction in the proportion and even the absolute number of patients in geriatric wards of hospitals and in psychiatric hospitals at the same time as the elderly population has increased. On the other hand, the expression of this problem and the organization of appropriate forms of care must not be allowed to overshadow the needs of non-disabled residents at the other end of the disability scale. A large proportion of residents are quite active and alert and could happily live in a less constrained and regulated environment in sheltered or special housing. The tasks of meeting their needs as well as those of the severely disabled residents are incompatible. ${ }^{\text {B0-67 }}$

\section{Forms of Social Dependence in Residential Care}

The evidence about capacity is important but arguably inconclusive in analysing the functions of Homes and the potentialities of residents. Obviously there can be anxious debates about the appropriateness of applying relatively crude measures of capacity and whether such measures can be used for fluctuating levels of capacity over short spans of time. For this reason among others we need also to consider a second set of evidence. If a high proportion of inmates do not satisfy the formal physical or clinical criteria for residence then there must be some key social determinants to be unravelled, whether to do with the social origins (or characteristics) of inmates or of the institutions in which they live. (This is not to say that social determinants are not also important in explaining the presence of incapacitated inmates.)

Let us consider the social evidence. Far from being a representative cross section of the elderly the inmates of institutions are very unrepresentative. Thus there is a consistent relationship between the 'closeness' of someone's familial network and his chances of being in an institution in old age. According to the census of 197 I relatively four times as many bachelors as married men and three times as many spinsters as married women of 90 years of age or over in Britain were in different types of institution. As many as 37 per cent of bachelors and 44 per cent of spinsters of this age were living in institutions. ${ }^{88-69}$ But marital status is a crude 
indicator of family status, and it is the familial situation which is the vital matter for study and measurement.

A 1963 study found that the chances of institutionalization for a bachelor or spinster of advanced age were higher than those for a widowed or divorced childless person, and the chances then decreased, step by step, for a married but childless person, then for someone with one son only, someone with one daughter only, someone with sons or daughters but living at a considerable distance from them or having little contact. with them and finally, the chances were least for someone with sons and daughters and having daily contact with them. This statement applies to each of the major types of institutions, though less markedly to geriatric hospitals than to psychiatric hospitals and residential Homes.

There is a corresponding 'gradient' in relation to incapacity. Those lacking a family network tend to be younger at admission, and less incapacitated, and live longer as residents or patients, than those with a close family network. ${ }^{70-i 1}$

The evidence therefore suggests that in part institutions emulate, or deputize for, families in providing care for certain elderly people whose family resources are meagre. In this sense they complement the family. But while this helps to explain the presence of sick, disabled or infirm people who lack, or have become isolated from, close relatives it does not explain the presence of relatively active or independent people. We then have to draw on various studies which show the scale of homelessness among single people - not only as a consequence of loss of job, failure to pay rent, or eviction from housing provided by an employer or a husband's employer, but dispossession of property during stays in hospital. This might be summarized as the loss of rights to housing in the community.

There are other external determinants of inmate status which can be understood most easily in terms of social deviance. There are elderly people who are labelled as 'confused' or 'wandering', 'forgetful', 'a danger to themselves', 'dirty', 'undernourished', 'restless' and 'aimless' and who are urged to move into a hospital or Home. The reason for their admission is more one of social disquiet, embarrassment or intolerance than that such people meet strict criteria of dependency or of the need for treatment or confinement.

Once we try to account for the continued residence of relatively active long-stay inmates our attention shifts from external to internal factors. Some people who are frail or malnourished when first admitted become stronger after a period of care. A Home or a hospital is an on-going social system. It may or may not enjoy strong relationships with external society. The number of visitors or inmates who have social contacts or relationships outside the precincts of the institution may be relatively small 
or large and in other ways it can be socially marooned or integrated. Goffman has helped us to comprehend the relative imperviousness of some institutions to external social change and the total, and sometimes frightening, authority exercised by some staff over inmates. ${ }^{72}$ Access to income is extraordinarily restricted and financial deprivation, as a source of extreme dependence, is rarely measured and analysed. In Britain, as in some other countries, there have been a scries of revelations about abuses occurring in long-stay institutions. Since the late 1960 , in particular, there have been a stream of reports on individual mental illness, mental handicap and geriatric hospitals and residential Homes which have revealed conditions and staff practices which are socially unacceptable. ${ }^{73-75}$ Many of these reports have emanated from official inquiries - in particular those of the Hospital Advisory Committee. It is important to appreciate that problems arise not only in the forbidding environment of the largest long-stay hospitals but also in both small private Homes and brand-new local authority Homes. Let me give two examples. The authority of the matron in a small private Home for six or ten residents can often be close to total and society has failed either to properly investigate or prevent abuses. Secondly, fear of being transferred to an old institution has operated as a sanction to control the behaviour of residents and even elderly residents in many local areas. Many councils have been slow to close these old buildings, and some are still used. But as their numbers have diminished new forms of control are being developed. For example, separate wings or units of some newly built Homes have been reserved for the elderly mentally infirm. ${ }^{76}$ An early report on such arrangements, which is certainly the finest post-war study of the subject, severely criticized them. ${ }^{77}$ Unhappily social deviants or miscreants and not only those categorized as mentally infirm tend to be allocated to such units and although there has been some discussion ${ }^{78-80}$ the case against these units needs to be discussed much more openly, and anxiously, than it is.

Socially, then, institutions are structured to serve purposes of controlling inmates. The type and level of staffing, amenities and resources have been devcloped not only in relation to the characteristics, including the perceived capacities, of inmates but also the roles staff expect inmates to play. Staff tend to resist any increase in the number or proportion of inmates requiring a great deal of attention. They become conscious of the value of inmates who perform large and small tasks in the organization and tend to give excuses rather than rational grounds for the presence in the institution of these inmates. On the other hand, the roles are distinguished from those played by staff by their subordinate and even menial status and the derisory forms of payment which accompany them. Occupational roles are clearly distinguished partly to maintain the lower status and 
presumed dependency of inmates. The majority of residents in Homes are placed in a category of enforced dependence. The routine of residential Homes, made necessary by small staffs and economical administration, and committed to an ideology of 'care and attention' rather than the encouragement of self-help and self-management, seems to deprive many residents of the opportunity if not the incentive to occupy themselves and even of the means of communication. These statements are based on a large number of citations. ${ }^{81-99}$

Many of these phenomena have also been documented in other countries, ${ }^{100-103}$ though to my mind the plight of the elderly is not fully revealed and the implications for changes in the direction of policy not fully spelt out because many of the studies adopt the contemporary values of capitalist society. For example, following a book describing elderly people and old age institutions in the United States as a whole and giving a more detailed picture for three states: Massachusetts, Virginia and Utah, a second book reporting studies of $25^{8}$ institutions in these three states was published in 1977. The authors assemble cvidence to challenge 'the present trend towards patterning OAI along the lines of the hospital model.' Yet there is an element of pretence. 'Sophisticated medical science is largely absent from OAI.' They are also 'authoritarian organizations in which residents are low status. . . authority is informal, arbitrary and ultimately coercive'. In the words of Theodore Caplow, writing the foreword, 'the most serious problems, it seems to me, are these: the imposition of an inappropriate medical model on old-age institutions as a condition of receiving public funds; the increasing unresponsiveness of these institutions to residents' preferences, and the routinized disregard of resident's civil rights... Many residents of old-age institutions are as effectively incarcerated under the present system, as they would be in prison. ${ }^{104-105}$

The different types of institution, and not just individual institutions, might also be said to constitute a 'system' - not only in the formal sense of providing complementary forms of care, and trading between each other, but reflecting, if a little disjointedly, the class system. There are lavishly appointed private residential and nursing Homes for the wealthy, Homes for members of certain professions and different categories of local authority Homes - former workhouses, converted large houses, usually on the outskirts of towns or in the country districts, and purpose-built Homes - for people of former manual and lower non-manual status. In Britain private and voluntary Homes form a smaller proportion of total residential accommodation than in countries like the United States but none the less account for a substantial number of places and reflect different class opportunities. Thus, in the I969 Scottish study, 57 per cent of residents of private Homes, $3^{1}$ per cent in voluntary Homes and only 16 per cent 
in local authority Homes were of former non-manual occupational status. ${ }^{108}$ A 1963 survey of inmates of the three types of institution showed that relatively fewer middle-class persons and more working-class persons from partly skilled and unskilled occupations were to be found in psychiatric hospitals than in residential Homes and geriatric hospitals. Although numbers in certain categories were small this held true for short-, mediumand long-stay inmates. No explanation for this class difference could be found in the data about incapacity, lucidity and family origins - though it seemed that people of low occupational status who also lacked articulate relatives to speak for them were especially liable to find their way into institutions of low status and poor facilities.

This brief account of the sociology of institutions for the elderly would not be complete without some attempt to indicate trends in the patterns of care and the influence of policy. In 1971346,000 of the $7,130,000$ people in Britain aged 65 and over, or 4.8 per cent, were in residential Homes, psychiatric hospitals and other hospitals. ${ }^{107}$ The proportion was certainly higher in I II (probably about 6 per cent although there is a minimum estimate, based on official data, of 5.3 per cent for that year) but had been lower in 1951 ( 3.5 per cent). Between 1961 and 197 I the figure increased only very slightly, and when weighted according to the distribution by age of the elderly population represented an even smaller increase. Within the total there has been a steady increase in the proportion in residential Homes but a decrease in the proportion in hospital. DHSS evidence for mental illness and mental handicap hospitals in England for the 1970s shows a continuing absolute as well as relative decline in numbers of patients. There have been different factors influencing the trend. Professional beliefs about therapy and the balance that should be struck between policies of active treatment or rehabilitation and of mere containment or attendance have changed. Fewer hospital staff seem prepared to accept long-stay patients as one of their functions. The relative increase in the population of residential institutions is due not only to a disproportionate increase of the elderly in the population but also to more discriminating procedures in hospital of admitting patients and securing early discharge. Turnover has become a criterion of success in administering hospitals and those working in long-stay hospitals, especially geriatricians and psychiatrists, have adopted more active ideologies of treatment. They have found it possible to maintain or even increase resources, including staffing ratios, while shedding patients.

The maintenance and even increase of the share of resources going to hospitals and to residential institutions has been something of a paradox. Despite the powerful movements in favour of community care the emergence of that sector cannot be said to have properly materialized. This is 
not easy to explain. The failure to achieve a shift in priorities has to be explained partly, as I have implied, in relation to the powerful vested interests of certain branches of the professions, unions of hospital staffs and certain sections of the administration. The brute fact is that the majority of medical staff and the vast majority of nursing staff work in hospital, and the majority of local authority care staff work in residential Homes. The failure to shift the balance of health and welfare policy towards community care also has to be explained in relation to the function of institutions to regulate and confirm inequality in society, and indeed to regulate deviation from the central social values of self-help, domestic independence, personal thrift, willingness to work, productive effort and family care. Institutions serve subtle functions in reflecting the positive structural and cultural changes taking place in society.

The numbers of bedfast, severcly incapacitated and infirm old people living in the community dwarfs the number in institutions and there are real dangers in the present situation of committing available resources for the care of a few at the expense of the much larger number living in the community who require only modest forms of support to live independently with their families. ${ }^{108-112}$ Our object must be a renewed attempt to replace institutional care by increased and new forms of support in the home. While the costs of care in residential institutions are not always easy to compare with the costs of providing alternative services when old people are living at home (depending on levels of disablement as well as the types of benefit or service included in the measurement) most of the studies that have been carried out have concluded that the costs of care at home are smaller. ${ }^{113-115}$

However, so much energy has been invested by radical analysts in arguing for community care as an alternative mode of support for the elderly that some of the less happy practices incorporated within the conventional administration of community care services have attracted little scrutiny. Thus, day centres are sometimes organized on the same lines as residential Homes, but without residence at night. Meals and perhaps physiotherapy are laid on but little scope allowed for various forms of occupation and self-management. The duties of home helps and community nurses are also heavily circumscribed. The elderly are usually viewed as the grateful and passive recipients of services administered by an enlightened public authority. This can but reinforce their dependency both in their own eyes and that of the public. The possibility of organizing collaborative services with elderly clients and non-clients would be regarded in most areas as entirely alien or utopian. 


\section{SUMMART}

I have tried to argue that the concepts of retirement, pensionable status, institutional residence and rather passive forms of community care have been developed in both capitalist and state socialist countries in ways which have created and reinforced the social dependency of the elderly. Such 'structured' dependency is a consequence of twentieth-century thought and action, and especially of the management of modern economies and the distribution of power and status in such economies. The severity and extent of that dependency cannot be justified by appeal to certain major types of evidence. Empirical studies of capacity and desire for productive occupation, reciprocation of services, and familial and social relationships, as well as self-care, challenge the assumptions which prevail. There is clearly room for an alternative interpretation of the roles to be played by the elderly whereby many more of them continue in paid employment, find alternative forms of substantial and productive occupation, have rights to much larger incomes, and have a much greater control over the place and type of accommodation where they live, and the kind of community services to which they contribute as well as have access.

\section{NOTES}

I It is not easy to trace the origins of such a theme and explain why I now choose to attach such importance to it. The choice arises from work I have done with colleagues and alone and from the work of others. The dependency created by institutions is documented in my book The Last Refuge, London, Routledge, 1962; and the dependencics of retirement and poverty in The Family Life of Old People, Iondon, Routledge, 1957 (summarily), in later publications and, most recently in Poverty in the United Kingdom, Harmondsworth, Penguin Books, 1979. With Ethel Shanas, Dorothy Wedderburn and others I participated in a wide-ranging cross-national study of the elderly in Denmark, Britain and the United States, the chief conclusion of which was to call attention to the 'dual' relationship of the elderly to industrial society. Many of their problems, we stated, 'arise as the consequence of formal actions on the part of mass society that confirm their separate retired status'... They comprise 'a special category in society... a potential or embryonic class accommodated uneasily in the present class structure'. There was a 'balance between the integrative impulses of informal primary relationships and the segregative relationships of formal industrial society'... (Shanas et al., Old People in Three Industrial Societies, Iondon, Routledge, I968, pp. 425-6). I also tried to bring some strands together within the concept of the 'structured dependency' of the elderly in recent papers ("The Changing Status of the Elderly in Industrial Society', Bologna, I977; 'The Care of the Elderly in Britain and Japan', 1978; 'Structured Depcndency in Old Agc', unpublished paper to Research Officers of Social Services Departments, March 1978). I gained much from the work 
in the rg6os of Yonina Talmon and C. C. Harris in relation to the development of this themc and latterly from the work of Anne-Marie Guillemard (for cxample, La Retraite, Une Mort Sociale and La Viellesse et l'Etat) and Alan Walker (particularly his paper on the creation of dependency in old age, 1980). I am glad to acknowledge with gratitude the help of Alan Walker and Malcolm Johnson in revising this paper (first presented to the annual meting of the Canadian Association of Gcrontology, Saskatoon, Saskatchewan, I 8 October I980).

2 Donahuc, W., and Tibbitts, C., The New Frontiers of Ageing, Ann Arbor, University of Michigan Press, 1957.

3 Tibbitts, C., Handbook of Social Gerontology, Chicago, University of Chicago Press, 1960.

4 Atchlcy, R., and Seltzer, M., The Sociology of Ageing: Selected Readings, Belmont, California, Wadsworth, 1976. And see also Stearns, P. N., Old Age in European Society, London, Croom Helm, 1977; and Clark, R. L., and Spengler, J. J., The Economics of Individual and Population Ageing, Cambridge, Cambridge University Press, 1980.

5 Townsend, P., 'The Care of the Elderly in Britain and Japan: the Relative Effectiveness of Community Care and Residential Services for the Elderly', Paper given to the Japanese National Committee of the International Council on Social Welfare, April, 1978, published in Japanese, Tokyo, 1979 (English version in mimeograph).

6 Cumming, E. and Henry, W. E., Growing Old, New York, Basic Books, r96r.

7 Cumming, E., 'Further Thoughts on the Theory of Disengagement', International Social Science Journal, XV, 3, 1963.

8 Talmon, Y., 'Dimensions of Disengagement. Ageing in Collective Settlements', paper given at research seminar on social gerontology, Markaryd, Sweden, I 963 .

9 Talmon, Y., 'Ageing in Israel, A Planned Society', American Journal of Sociology, Vol. LXVII, No. 3, I96r.

ro Talmon, Y., Family and Community in the Kibbutz, Cambridge, Mass., Harvard University Press, I972.

I I See, for example, Hendricks, J., and Hendricks, C. D., Ageing in Mass Society, Cambridge, Mass., Winthrop, 1977.

12 Shanas, E., et al., Old People in Three Industrial Societies, London, Routledge, 1968.

13 Goftman, E., Asylums: Essays on the Social Situation of Mental Patients and Other Inmates, Garden City, N.Y., Doubleday Anchor, I96r.

14 Rothman, D., The Discovery of the Asylum, Boston, Little, Brown and Co., I97I, p. xix.

15 Henry, J., Culture Against Man, New York, Random House, 1965. Roth, J. A., and Eddy, E. M., Rehabilitation for the Unwanted, New York, Atherton, I 967.

I6 Scull, A., Decarceration, Englewood Cliffs, New Jersey, Prentice-Hall, 1977.

I 7 Townsend, P., The Last Refuge, London, Routledge and Kegan Paul, I962.

I 8 Thompson, E. P., The Making of the English Working Class, London, Victor Gollancz, 1963, p. 295.

19 Johnson, M. L., 'Relations and Relationships', Block I, Unit 4 of the Postexperience Courses Unit, Course, An Ageing Population, Milton Keynes, The Opcn University Press, 1979.

20 Thomson, D., Provision for the Elderly in England $1830-1908$, University of Cambridge, Ph.D., r981. 
2 I Frobel, F., Heinricks, J. and Kreye, O., The New International Division of Labour, Cambridge University Press, 1980.

22 Shanas, E., et al., Old People in Three Industrial Societies, Iondon, Routledge, I 968.

23 Parker, S., Older Workers and Retirement, OPCS Social Survey Division, London, HMSO, 1980.

24 Townsend P., Poverty in the United Kingdom, Harmondsworth, Middlesex, Penguin Books, 1979. See especially Chapter 19.

25 Ministry of Pensions and National Insurance, The Financial and Other Circumstances of Retirement Pensioners, London, HMSO, 1966.

26 DHSS, 'The DHSS Perspective', in Barnes, J. and Connelly, N., Social Care Research, Iondon, Bedford Square Press, 1978.

27 Townsend, P., Poverty in the United Kingdom, op. cit., Chapter 7.

${ }_{28}$ Wedderburn, D., 'The Financial Resources of Older Pcople', in Shanas, E., et al., op. cit.

29 Townsend, P., Poverty in the United Kingdom, op. cit., Chapter 20.

30 Shanas, et al., op. cit., Chapters 5 and 4 .

3I Morgan, J. S., 'Social Welfare Services in Canada', in Oliver, M., (ed.), Social Purpose for Canada, Toronto, University of Toronto Press, I961.

32 Thomson, D., op. cit.

33 DHSS, Conference on the Elderly; Background Paper, 26 July, 1977.

34 Kidd, G. B., 'Misplacement of the elderly in hospital', British Medical Journal, 2, 1962.

35 Mezey, A. G. Hodkinson, H. M. and Evans, G. J., 'The elderly in the wrong unit', British Medical Journal, 3 , ig68.

36 Carstairs, V., and Morrison, M., The Elderly in Residential Care, Scottish Health Service Studies, No. 19, 1971.

37 Townsend, P., 'The Needs of the Elderly and Planning of Hospitals', in Canvin, R. W. and Pearson, N. G., Needs of the Elderly for Health and Welfare Services, University of Exeter, 1972.

$3^{8}$ Wilkin, D., Mashiah, T. and Jolley, D. J., 'Changes in behavioural characteristics of elderly populations of local authority homes and long-stay hospital wards, 1976-7', British Medical Journal, 2, 1978.

39 Wilkin, D. and Jollcy, D. J., Behavioural Problems Among Old People in Geriatric Wards, Psychogeriatric Wards and Residential Homes, 1976-1978. Rescarch Section, Research Report No. 1, 1979.

40 Townsend, P., The Last Refuge, London, Routledge, 1962; 'The Necds of the Elderly and the Planning of Hospitals', op. cit.

41 Townsend, P., 'The Needs of the Elderly, and the Planning of Hospitals', $o p$. cit., pp. 53-4.

42 Bebbington, A. C., 'The Elderly at Home Survey: Changes in the Provision of Damiciliary Social Services to the Elderly Over Fourten Years' (mimeo), University of Kent, 1978. Bebbington, A. G., 'Scaling Indices of Disablement', British Journal of Preventive and Social Medicine, 3 I, 1977. Munnichs, J. M. A. and van den Heuval, W. J. $\Lambda$., Dependency and Interdependency in Old Age, The Hague, Martinus Nijhof, 1976. Harris, A. I., with Cox, E. and Smith, G. R. W., Handicapped and Impaired in Great Britain, OPCS, London, HMSO, 1971 .

43 Townsend, P., The Last Refuge, London, Routledge, 1962. And see also Townsend, P., 'The Needs of the Elderly and the Planning of Hospitals', op. cit., p. 54 .

44 Carstairs, V. and Morrison, M., op. cit., p. 74. 
45 Department of Health and Social Security, The Census of Residential Accommodation, 1970. Volume I: Residential Accommodation for the Elderly and the Younger Physically Handicapped, London, HMSO, I975, p. 44.

46 Carstairs, V. and Morrison, M., op. cit.

47 Shreeve, M., 'A Survey of Pcople Admitted to Old Peoples' Homes and on the Waiting List over a three-month period', Internal Report, Warwickshire Social Services Department, I973.

48 Kimbell, A. and Townsend, J., Residents in Elderly Persons Homes, Cheshire County Council Social Services Department, April 1974.

48a Townsend, J. and Kimbell, A., 'Caring regimes in elderly persons' homes', Health and Social Service Journal, is October 1975.

49 East Sussex County Council Social Services Department, Key Issue I: The Elderly: Main Report on the findings, 1975.

50 Smith, R. G. and Lowther, C. P., 'Follow-up study of two hundred admissions to a residential home', Age and Ageing, 5 ,3, 1976.

51 Whitfield, J, and Symonds, J., Alternatives to Residential Provision for the Elderly, Essex County Council Social Services Department, 1976.

52 Townsend, P., The Failure to House Britains' Aged, London, Help the Aged, 1976.

53 Hare, E. J., Three Score Years and Then?: A Study of Practical Alternatives to Residential Care, Norfolk County Council, 1977.

54 Plank, D., Caring for the elderly: report of a study of various means of caring for dependent elderly people in eight London Boroughs, Research Memorandum, Greater London Council, 1978.

55 Oldfield, J. J. and Whitbread, A. W., At Home or in a Home? Warwickshire Social Services Department, April 1978.

56 DHSS, Social Work Service, Iondon Region, Residential Care for the Elderly in London, January 1979.

57 Clarke, M., Hughes, A. D., Dodd, K. J., Palmer, R. I.., Brondon, S., Holden, A. M. and Pearce, D., 'The elderly in residential care: patterns of disability', Health Trends, 11 , 1979 .

58 Booth, T., 'Measuring Dependency', Community Care, 3 I January ig8o, pp. 15-18.

59 Bond, J., 'Dependency and The Elderly: Problems of Conceptualisation and Measurement', in Munnichs, J. M. A. and Van den Heuvel, W. J. A., Dependency or Interdependency in Old Age, The Hague, Nijhoff, 1976.

60 Bosanquet, N., A Future for Old Age, London, Temple Smith, 1978.

6 I Brearley, C. P., Residential Work with the Elderly, Routledge, 1977.

62 Brocklehurst, J. C. and Shergold, M., 'What Happens when Geriatric Patients Leave Hospital?', The Lancet, 23 November 1968.

63 Exton-Smith, A. and Grimlcy Evans, J., Care of the Elderly: Meeting Challenges of Dependency, London, Acadcmic Press, 1977.

64 Harris, A. I., Social Welfare for the Elderly, Government Social Survey, Vol. r, London, HMSO, rg68.

65 Isaacs, B., Livingstone, M. and Nevillc, Y., Survival of the Unfittest: A Study of Geriatric Patients in Glasgow, London, Routledge, 1972.

66 McLauchlin, S., Report of a Survey of Dependency Levels in Elderly People in Residential Homes and Hospital Accommodation on Tameside, Unpublished, 1979.

67 Sumner, T. G. and Smith, R., Planning Local Authority Services for the Elderly, London, Allen and Unwin, 1969.

68 Census, 1971, Non-Private Households, London, HMSO, 1975, p. 124. 
69 Johnson, M. L., op. cit.

70 Townsend, P. and Wedderburn, D., The Aged in the Welfare State, London, Bell, ig65.

$7_{1}$ Townsend, P., 'The Needs of the Elderly and the Planning of Hospitals', op. cit.

72 Goffman, E., op. cit.

73 Reports of the Committee of Inquiry into Allegations of Ill-Treatment of Patients and other Irregularities at the Ely Hospital, Cardiff, Cmnd. 3975, London, HMSO, 1969.

74 Robb, B., Sans Everything: A Case to Answer, London, Nelson, 1968.

75 Findings and Recommendations Following Enquiries into Allegations Concerning the Care of Elderly Patients in Certain Hospitals, Cmnd. 3687 , London, HMSO, Ig68.

76 DHSS, The Census of Residential Accommodation, 1970, op. cit., p. 93.

77 Meacher, M., Taken for a Ride, London, Longmans, 1972.

78 Pasker, P., Thomas, J. P. R. and Ashley, J. S. A., 'The elderly mentally ill whose responsibility?', British Medical Journal, 3, 1976.

79 Peterson, M., Confusion More Confounded - A Study of Separatism in a Home for the Elderly, Department of Sociology, University of Essex, I976.

8o Wilkin, D. and Jolley, D. J., 'Mcntal and physical impairment in the elderly in hospital and residential care', Nursing Times, 74, 29 and 30, I978.

8 I Burrage, M. and Phillips, D. (eds), Nine Old People's Homes in a London Borough, London School of Economics, 1973.

82 Glarke, M. et al., 'The Elderly in Residential Care: Patterns of Disability', Health Trends Vol. II, No. I, February 1979.

83 Davies, B. P. and Knapp, M. R. J., Old People's Homes and the Production of Welfare, London, Routledgc and Kegan Paul, (in press) 1980.

84 Fiske Jowenthal, M., Lives in Distress, New York, Basic Books, Ig64.

85 Fiske Lowenthal, M., 'Social Isolation and Mental Illness in Old Agc', American Sociological Review, 1963.

86 Isaacs, B. et al., Studies of Illness and Death in the Elderly in Glasgow, Scottish Health Service Studies No. I7, Scottish Home and Health Department, Edinburgh, 1971.

87 Jelf, P., 'A Survey of the Population of the Social Services' Department's Homes for the Elderly as at 9 March 1976', Clearing House for Local Authority Social Services Research No. 6, 1976.

88 King, R. D., Raynes, N. V. and Tizard, J., Patterns of Residential Care, London, Routledge and Kegan Paul, r97I.

89 Lipman, A. R, and Slater, R., 'Homes for old people - towards a positive environment', Gerontologist, I 7, 1977.

9o Lowther, G. P. and MacLeod, H. M., 'Admissions to welfare home', Health Bulletin, 32, I, 1974.

9I Ministry of Health, Residential Accommodation for Elderly People, London, HMSO, 1966.

$9^{2}$ Peace, S. M., Hall, J. F. and Hamblin, G. R., 'The Quality of Life of the elderly in residential care', mimeo, Survey Research Unit, The Polytechnic of North London, I979.

93 Personal Social Services Council, Residential Care Reviewed, London, 1977.

94 Rees, A. M., Old People and the Social Services: A Study in Sunderland, Department of Social Administration, University of Southampton, 1972.

95 Shiphorst, B., 'Some Aspects of Residential Care', Social Work Service, No. 10 , July 1976 . 
96 Spasoff, R. A., Kraus, A. S., Beattie, E. J., Holden, D. E. W., Lawson, J. S., Rosenburg, M. and Woodcock, G. M., A longitudinal study of elderly residents of long-stay institutions, Gerontologist, $18,1978$.

97 Townsend, P., The Last Refuge, op. cit.

98 Meacher, M., op. cit.

99 Peterson, M., op. cit.

Ioo Ilenry, J., op. cit.

Ior Roth, J. A. and Eddy, E. M., op. cit.

I02 Tobin, S. S. and Lieberman, M. A., Last Home for the Aged, New York, Jossey-Bass, 1976.

I03 Scull, A., op. cit.

I04 Bolling Manard, B. Woehle, R. E. and Heilman, J. M., Better Homes for the Old, Lexington, Mass., Lcxington Books, 1977, pp. xiv, 3 I, I 35.

105 See also Bolling Manard, B., Kart, C. S., Van Giles, D. W. L., Old Age Institutions, Lexington, Mass., Lexington Books, 1975.

ro6 Carstairs, V. and Morrison M., op. cit., p. 40.

I07 Based on Census, I97 I, Non-Private Households, op. cit.

Io8 Abrams, M., Beyond Three Score and Ten, Agc Concern, London, Ist Report, I978, 2nd Report, r980.

109 Booth, T., 'Finding Alternatives to Residential Care - The Problem of Innovation in the Personal Social Services', Local Government Studies, July 1978.

I 10 Hunt, A., The Elderly at Home. A Study of people - aged 65 and over living in the community in England in 1976, Office of Population Censuses and Surveys, Social Survey Division, London, HMSO, 1978.

I I I Davies, B. and Knapp, M., 'Hotel and Dependency Costs of Residents in Old Pcoples' Homes', Journal of Social Policy, January 1978.

I 2 Economist Intelligence Unit, Care with Dignity, National Fund for Research into Crippling Diseases, 1973.

113 Wager, R., Care of the Elderly, London, Institute of Municipal Treasurers and Accountants, 1972.

I 4 Moroney, R. M., The Family and the State, London, Longmans, 1976.

I I5 Morc complex conclusions were reached in work supervised by L. J. Opit. See, for cxample, Opit, L. J. and Shaw, S. M., 'Care of the Elderly Sick at Home: Whose Responsibility is it?' The Lancet, 20 November 1976; and Opit, L. J., 'Domiciliary Care for the Elderly Sick', British Medical Journal, I January 1977. 